\title{
小児甲状腺癌例の検討
}

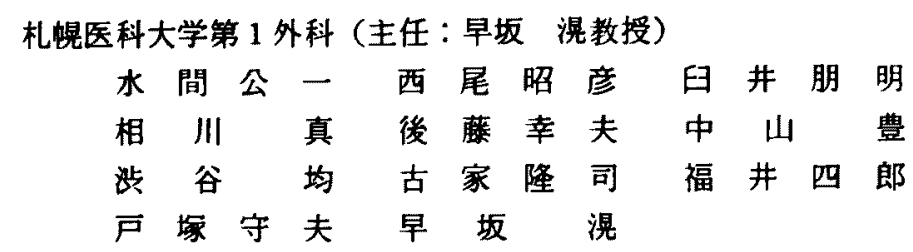

\section{ANALYSIS OF CASES OF THYROID GARGINOMA IN CHILDHOOD}

Koichi MIZUMA, Akihiko NISHIO, Tomoaki USUI, Makoto AIKAWA, Yukio GOTO, Yutaka NAKAYAMA, Hitoshi SHIBUYA, Takashi FURUYA, Shiro FUKUI, Morio TOTSUKA and Hiroshi HAYASAKA

First Department of Surgery, Sapporo Medical College (Director : Professor Hiroshi HAYASAKA)

甲状腺癌は他搭器の癌に比べ発症年龄のピークは若年者側にある。しかし小児症例は多 くはないが著者らは教室における経験例を中心に診断，治療の面について検討を加えた． 術前から癌の確訅をえた症例は少なく，早期猃断と治療が要求される小児例においてい甲

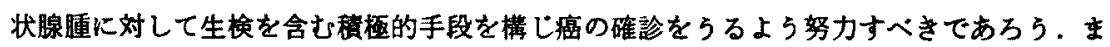
た衍式は，高い根治性と最小の合併症が要求されるため傎重に各症例に最適な街式を摆択 すべきである.予後は成人とほ注同様に良好と考えてょいと思われるが，死亡原因の大半 を占める肺転移に対する対策は今後さらに検討・改善を加光てゅくべきと思われる.

\section{はじめに}

小贸における甲状腺薙は先天性，奇形性の機能低下 を示すすのむあるが，バゼウ病が多く甲状腺癌は稀れ と考えられている.

一般的に甲状腺播の予後は良好で手術後の10年生存率 は約80\%と報告されている゙．しかし小睍例では局所リ ンバ節また肺への転移率が高いとも云われ2治療の面で さらに検討されるべき問題があると考えられる. 今回， われわれは数室において過去16年間に経験した小児甲状 腺癌症例 4 例を中心に倹討を加えたのて報告する．

应例 1. I.S. 15留, 女性

主沂 : 前頝部の尰張

現病歴：生来踺康, 5 力月程前より前䫓部, とくに左 側に腫張が見られるよらになった。発熱疼痛などの自覚 症状はない，多开，体重隇少，動悸などの甲状腺機能六 進を疑わせる所見むない，家族歴に特吭すへきことな
し、暊部腫脤は、次第に增大㑯向を示したために当科受 診する。

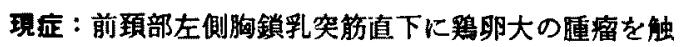
れるが王痛, 発赤は認めない，睡瘤の表面は平滑，弾性

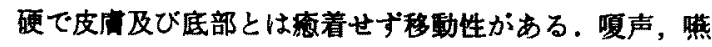
下障害はない。

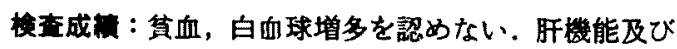
血清電解質は正常，水に異常所見を認めない. BMR は $+8 \%,{ }^{131}$ I uptake test では24㭙間で11.7\%といずれ る正常範囲であった。

手術所見: 昭和 39 年 3 月 18 日手術施行, 前顓部横切開 で甲状腺前面に達する。腫埸は $2.5 \times 3 \mathrm{~cm}$ で左藮全体を 占めていた，峡部で甲状腺を切断し，左葉切除を行っ た、リンパ廊清は施行していない，なお，手術後にコハ ルト照射を行った。

病理組期所見 : follicular-papillary adenocarcinoma. 应例 2. T.M. 15歳, 男性 


\section{主訴：右前頝部腫緭}

現病歴：5 年ほど前より右前預部に母指頭大の尰瘤の あることに気付いていたがとくに自覚症状がないため放 㯰していた．来院の数々月前より次第に盾瘤が增大して きた，某外科からの紹介により当科入院となった，家族 歴に特記すべきことなし，ただ既往歴に気管支結核と云 われ治療したことがある。

現应：右前預部胸鎖乳突筋前縁に $3 \times 3 \mathrm{~cm}$ の円形の 腫瘤を触れる。弾性硬で表面は顆粓状一部不整な塊状を 示す部分るある．皮㡱及び底部とは病着なく移動性があ る。また右側䅡部に大豆大から小指頭大のリン八節と思 われる腫瘤数個を触れた。腫瘤には発赤, 压痛, 波動等 を認めない。

検查成楼：貧血なく，白血球增多も認めない，肝機能 を含め血液生化学的検索で異常值はない，BMR 他甲状 腺機能検査は実施していない。

手術所見 : 昭和 39 年 5 月 18 日手術施行, 前頝部横切開 で甲状腺に達するに右葉は硬い、結節状腫瘤で占められて おり凍結迅速診断では悪性であったため峡部から甲状腺 右葉を切除し，さらに右側顐部のリン・激清を行った。 手術後コバルト照射施行した。

病理組所見 : papillary-follicular adenocarcinoma $の$ 診断であり上下内深預リンパ節群に転移を認めた（图 1 ).

経過：術後 6 カ月まで再発の徵はなかった。

症例 3. S.S. 14歳, 男性

主訴：前頝部腫瘤

現病歴： 5 カ月前より家族に前頝部の腫瘤を指摘され るもとくに自覚症状ないため放置していた，最近になり

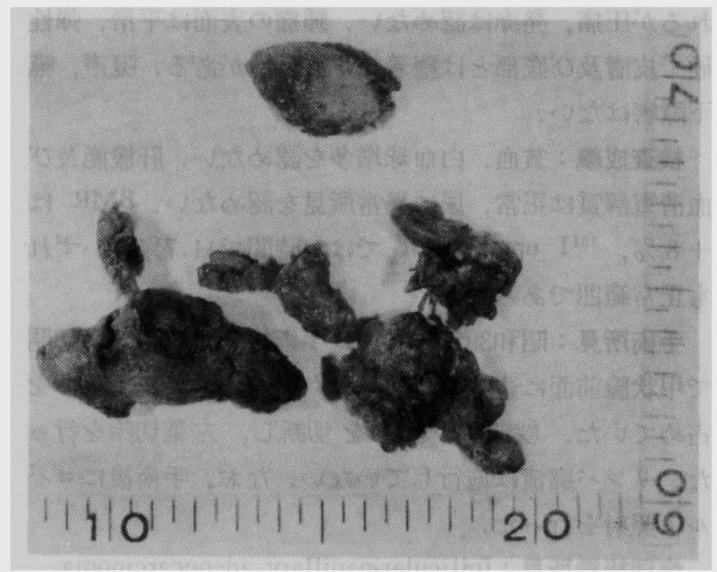

図 1 症例 2 の摘出リンパ節
腫瘤が増大する感じがあり某医にて手術をすすめられ当 科入院となった。発熱，疼痡，㖽声等はなく，体重減 少，振崸，動悸も自覚していない，既往歴，家族歴にも 特記すべきことはない。

現症：右前頖部が軽度に膨隆しており，甲状腺右葉に 相当する部分に腫瘤を触れる．腫瘤は弾性硬，表面平滑

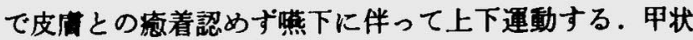
腺左葉は正常で周囲にリンパ節を触れない。

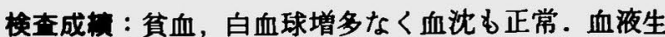
化学検査に異常值を認めない。 ${ }^{131}$ I 甲状腺シンチグラム で右葉に欠損を思わせる像を認めた（図2）。

手術所見：昭和 46年1月12日手術施行，前預部腫痹 下縁に一致した $5 \mathrm{~cm}$ の横切開で甲状腺右葉前面に達し た．腫瘤は母指頭大で一部甲状腺実質と窈着が認められ たが核出術を行った。迅速凍結診断では覀性所見なく follicular adenoma であった. しかし後日のパラフィン 切片による病理組織検査では follicular adenocarcinoma の診断であり，ただちに再手術を実施し右葉切除を追加 した．手術後はコバルト照射を施行している。

病理組澏所見 : 前項参照

経週：手術後 2 年前を経過して再発の徽なし。

应例 4 . M.T. 14歳, 男性

主訴：前頚部腫瘤

現病歴：当科受診約 1 年前に某医にて右結節性甲状腺 腫の手術を受けている．約 2 力月前より左前䫓部に腫瘁 を認めるよらになった。なお，前回手術時の組織所見は follicular adenoma であった。疼痛，呰下困難等の自覚

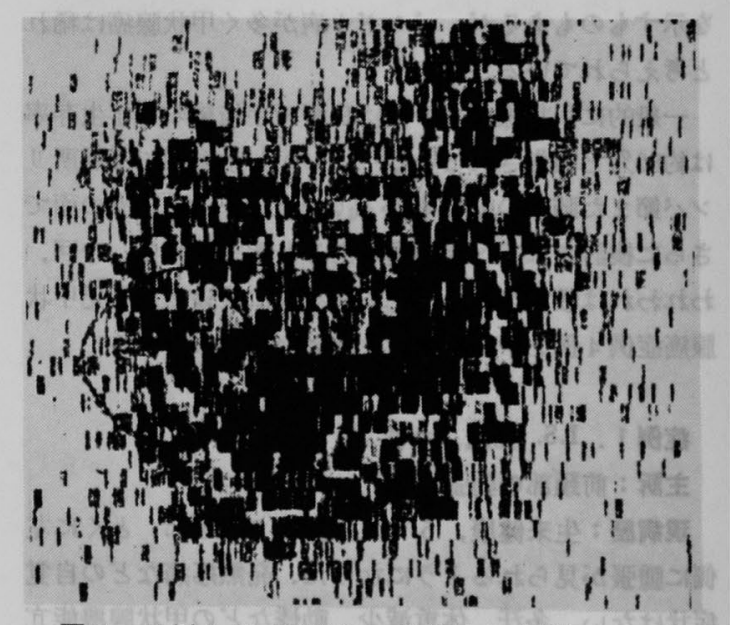

図2应例 3 の甲状腺シンチクララム( ${ }^{131}$ による) 
表 1 小児甲状腺畫后例

\begin{tabular}{|c|c|c|c|c|}
\hline 虚 例 & 1 & 2 & 3 & 4 \\
\hline 年 踰・珄 & 15 -女 & 15・男 & 14・男 & 14・男 \\
\hline 岸腅期間 & 5 力月 & 5 年 & 5 カ月 & 2 力月 \\
\hline 腫喑位 & 左莱全体 & 右葉全体 & 右莱中部 & 右葉中下部 \\
\hline 怯移・浸閻 & \& L & リンバ節坛移あり & L & $な$ \\
\hline 手術々式 & E葉切除 & 右葉切除・郭清 & 核出街に右葉切除を追加 & 垔全摘出 \\
\hline 㭪助袁法 & コバルト周射 & コバルト服射 & コバルト瑚 & な \\
\hline 䋘 & $\begin{array}{l}\text { follicular and papillary } \\
\text { adenoca }\end{array}$ & $\begin{array}{l}\text { papillary and follicular } \\
\text { adenoca }\end{array}$ & follicular adenoca & $\begin{array}{l}\text { papillary and follicular } \\
\text { adenoca }\end{array}$ \\
\hline 绎過 & 3 年間再発なし & 6 カ月再発なし & 2 年半再発なし & 3 年半再発极し \\
\hline
\end{tabular}

症状を認めず，家族歴，既往歴にも特記すべきことな い.

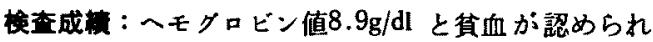
たが白血球增多症はなかった。血清フルカリフォスフフ ターゼ值の軽度上界が認められた他に血液生化学的な巽 常は認められなかった， $T_{3}$ レヂン䀸取率， $T_{4}$ 值は正常 籁囲であった。

手術所見：昭和51年 6 月 27 日手術施行, 左前顛部に約 $5 \mathrm{~cm}$ の横切開を加え, 前頊筋を切離・胸鎖乳笑缼を側 方に圧排して甲状腺左葉に達した．上極付近を小指頭大 残して垔全摘出した．周围のリンハ節仕触れなかった。 コバルト照射施行せり。

病理組域所見 : papillary-follicular adenocarcinoma $\sigma$ 診断であった。

経週： 3 年 6 カ月の锶察では再発の徵候はない（表 1).

\section{1. 病因}

考按

古くから頊部へのレントゲン照射が甲状腺癌の発症に 関与する可能性が指摘されていた，とくに米国では肥大 胸腺への照射が多数行なわれた経緯があり多数の報告が あるが，顓部へレントゲン照射を受けた既往のある者は 既往のない者に比べて 約700倍の高率で甲状腺癌が発生 さる可能性があるとの報告もあり"，また小児甲状腺癌 症例62例中13（21\%）飞肥大胸腺，預部リン八節炎， アデノイド等て頚部への照射歴があったと述へてている例 むある゙。しかし一方，本邦ては小児甲状腺癌に抽ける 放射線被曝の関与を示例は少なく，伊藤らの22例の経 験でも照射歴があったのはわずか1例にすぎなかったと 報告されている5゙．われわれの症例です過去に頊部にレ
ントダン照射を受けた例はなかったが，照射歴の有無は 必ずしむ明確でない場合もあると考えられ，病磨聴取の 仕方にむ考虑が必要とむ思われ，この点からすれば頻度 は增加する可能性むあるう。

遺云的，家族的発生については否定的な見解が一般的 である。

\section{2. 頻度・性比}

16年間に括忛る教室の全甲状腺癌症例恃図 3 に示すご とく234例であり30代から40代にかけて症例が多いが20 代です40例と可成りの頻度があった．15歳以下の小児例 は4 例で，これは全症例中の $2 \%$ にあたる。欧米では10 \%の頻度の報告もあるか，本邦では遠藤らは8.3\% ） 内野らは $5.5 \%$ 光述へているが一方，三村らの1\%以

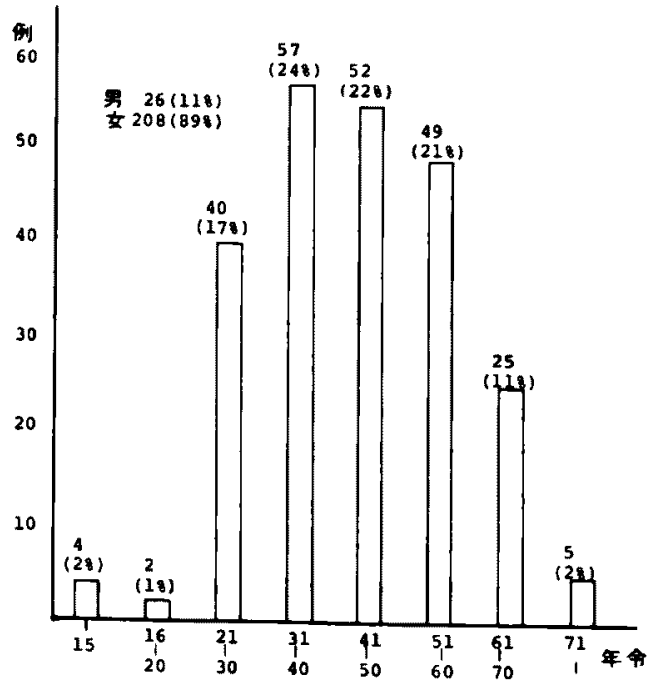

图 3 教室甲状腺路例の年令，性比の分布 


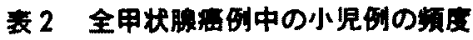

\begin{tabular}{|c|c|}
\hline Buckwalter ${ }^{7 \prime}(1961)$ & $15 / 144(10.4 \%)$ \\
\hline Exelby" (1967) & $62 / 1214(5.19)$ \\
\hline Roehe $^{8)}$ (1972) & $9 / 168(5.4 \%)$ \\
\hline 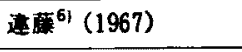 & $6 / 72(8.3 \%)$ \\
\hline 内野 ${ }^{31}$ (1975) & $7 / 127(5.5 \%)$ \\
\hline 三村2) (1979) & (1\%以下) \\
\hline 著者（1980） & $4 / 234(1.7 \%)$ \\
\hline
\end{tabular}

下との報告2るあり多いあのではない，表2 は頻度につ いての報告をまとめたものであるが，欧米及び本邦とも に年代の経過ととむに頻度が隇少していることは注目す べき点である. 教室全甲状腺癌庭例の男女比は1：9で あったが自験 4 例は $3 ： 1$ の此であり諸家の報告と一致 して小児症例では男性の占める割合いが多いことを示し ている.

\section{3. 应状と病悦期间}

初発症状は自験 4 例全部が無痛性の顥部腫㙁であり， リンバ節を触れた1例を除き他は甲状腺腫であった。甲 状腺機能の異常を示した患者はなかった。 また成人例で はときに認められる呼吸困難，嗄声等の应状を呈した例 は自検例中にはなかった。この点は三村らの集計”と同 様の結果であった。

病脳期間は最短 2 力月，最長は 5 年に及んでおり，串 祭の病脳期間はさらに長いるのと思われる，病脑期間の 長い、例では的確な治㞠方針が決定されすに経過観察を続 けた症例むあることは留意する必要のある点であった。

\section{4. 杉断}

前述したよらに甲状腺腫のみを应状として来院する例 が大部分であることからして，触診所見が重要なことは 云うまであないが，㬰際に螌診で癌の確診を得ることは 困難な面むあり，良性と䛦断されることも可成りあると 云われる”。教室例中術前癌と猃断されたのは顏部りン バ節転移の明瞭な1例のみであった。

補助猃断法として䫓部軟線撮影も行なかれるが, 悪性 畽場を示唆する石灰化像は20\%程度しか認められないと 報告”されており不確実である。放射性ヨードによる甲 状腺シンチダラムでは欠損として描出されるが一般的に 悪性腫湯，良性腫痬，炎症等の鑑別は困難である ${ }^{10)}$ 。こ のような点からして早期部断，早期治療が望まれる小児 甲状腺腫例ではある程度積極的な手術による生検むやむ を得ない面があり，穿刺吸引細胞診る考虑すべきるとと

\section{思われる ${ }^{11}$ 。}

\section{5. 組部型}

甲状腺癌の組織型は大別して分化癌と未分化癌にわけ られるが，小児例では大部分が分化痘であり未分化癌は

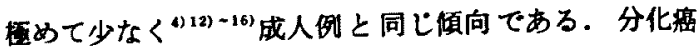
の5ち乳頭状腺癌が多数を占め全体の89.8 53.5\%とい われており，教室例では乳頭状腺癌が主なるの2 例, 演 胞状腺癌が主なる 2 例と $1 ： 1$ の比であった。

\section{6. 治就}

根治手術によってのみ完全治䰿が期待できることは他 の悪性腫瘍と同梯であるが，甲状腺癌には発育が遮い分 化癌が極めて多いことから手術々式については種々の主 張がある現状で，とくに小児例では手術後のより長期の 生存が期待されることから根治性の高い術式を選択しな ければならない反面，発育途上にあることす考虑しなけ ればならないと考えられ，術式の揳択には惧重を期され ばならない，教室例を含めて本邦諸家の報告では全摘出 を行った症例は $9.3 \%$ にすぎず他は片葉切除が $34.9 \%$ ， 亜全摘出が23.2\%等であった（表 3 ）。またりンバ節廄 清では radical neck dissection を予防的邡清として皘椣 的に行う例訬ないと思われる。しかし教室症例 2 のご とく初猃時にすでにリンバ節転移が明らかな場合には可 及的に合垪症の発生を防止しつつ積極的な neck dissectionを行うべを考える。

教室症例のらちで街後の補助療法として放射線治療を 施行した例があるがその好果は不明であり，現在は行な

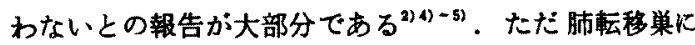
放射性ヨードの取り込みが認められる例では著效例啹

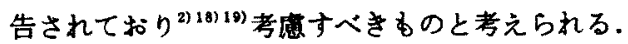

\section{7. 予滕}

小児甲状腺癌は比較的急速に発育し，転移を来たし やすいと云われ予後は成人例に劣るとの見解がある反 面 ${ }^{2}$ ，成人例より10年生存率が明らかに高いと述へる報

表 3 小児甲状滕绑に対する手術マ式

\begin{tabular}{|c|c|c|c|c|c|}
\hline 術 式 & 全捽出 & 恶全摘出 & 片菜切除 & 部分如除 & イルホプー \\
\hline 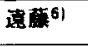 & 1 & 1 & 4 & & \\
\hline 桑山17) & 1 & & 3 & & \\
\hline 内野了! & 1 & 1 & 4 & & 1 \\
\hline 三村 ${ }^{21}$ & & 7 & 3 & 11 & \\
\hline 著者 & & 1 & 3 & & \\
\hline 計 & $(7.198)$ & $\begin{array}{c}10 \\
(23.896) \\
\end{array}$ & $\begin{array}{c}17 \\
(40.5 \%) \\
\end{array}$ & $\begin{array}{c}11 \\
(26.29) \\
\end{array}$ & $\begin{array}{c}1 \\
(2.4 \%)\end{array}$ \\
\hline
\end{tabular}


告す見られる は89.4\%湍胞状腺癌67.0\%との報告もある ${ }^{20)}$. 死亡原因 は肺に関するるのが大部分でありり", 今後の愉討が診 断, 治療の面から必要な点であろ5. 教室例は followup の期間が短いるのが多く結論は出せないが最長街後 3 年半でいずれの莚例にも再発は認めていない。

\section{洁 鯃}

教室における経駼例 4 例を中心に小児甲状腺㺕につい て訩断, 治療の面について㭘討を加えた。

1. 主訴は大部分は無痛性の前預部腫㽷であり, 初診 時に確定診断を下すことは困難であるため，生娭等積極 的に癌の確診を得るよら努力する必要がある。

2. 治療はより高い根治性が要求されると共に, 患者 が発育の途上にあることから術後合併庭の最少にとどめ る必要むあり、これらを両立させることが可能な術式を 摆択する要がある。

3. 予後は可成り良好と考えられるが肺転移に対して は対策をさらに検討すべきと考えられる。

\section{文献}

1）佐々木純：甲状腺畽場，総合臨床，29：882$886,1980$.

2) 三村 孝，榡 秀樹他：小児甲状腺癌22例の検 討, 小児外科, $11: 1571-1577,1979$.

3）内野純一, 今村文元, 茛西洋一地: 小児期甲状 腺癌, 外科診療, $17: 1453-1463 ， 1975$.

4) Exelby, P.E. and Frazell, E.L.: Carcinoma of the thyroid in children. Surg. Clin. $\mathbf{N}$. Amer., 49: 249-259, 1969.

5）伊藤国彦，三村 孝: 小児甲状腺疾患の外科， 小児外科，9：1235-1241，1977.

6) 遠藤辰一郎, 渡辺岩雄, 梅津昌光他 : 小児甲状 腺癌の臨床一特にその特異性について一，手 術, $21: 221-232,1967$.

7) Buckwalter, J.A.: Age and thyroid carcinoma. Arch. Surg., 82: 916-924, 1961.
8) Roeher, H.D., Pieper, M. and Rudolph, H.: Juvenile thyroid carcinoma. J. Ped. Surg., 7 : 27-31, 1972.

9) 栗原英夫, 高松正之, 小川将: 甲状腺外科の 実地診療，外科診療，20：1557-1566，1978。

10）原田種一，松土昭彦：結節性甲状腺尰の訩断之 治療, 外科診療, $20 ： 1534-1540,1978$.

11）鳥居城男：甲状腺腫の穿刺吸引細胞診，外科 Mook 7, 預部隀湯の臨床, 金原出版, 1979.

12) Duffy, B.J. and Fitzgerald, P.J.: Thyroid cancer in childhood and adolescence. Cancer, 3: 1018-1032, 1950.

13) Hayles, A.B., Kennedy, R.L., Beahrs, O.H., et al.: Management of the child with thyroidal carcinoma. J.A.M.A., 173: 21-28, 1960.

14) Winship, T. and Rosvoli, R.V.: Childhood thyroid carcinoma. Cancer, 14: 734-743, 1960.

15) Tawes, R.L. and DeLorimier, A.A.: Thyroid carcinoma during youth. J. Ped. Surg., 3: 210-218, 1968.

16) Harness, J.K., Thompson, N.W. and Nishiyama, R.N.: Childhood thyroid carcinoma. Arch. Surg., 102: 278-284, 1971.

17) 㯲山哲治, 岩㴊 真, 武藤輝一地: 小児甲状腺 癌の 4 例, 外科診療, $15: 621-624,1973$.

18) 藤本吉秀, 小原孝男 : 甲状腺分化癌（乳頭腺 癌, 滤胞腺癌）の鑑別診断と治療方針，多科診 療, $20: 1541-1547,1978$.

19）伊藤国彦, 西川義彦, 原田種一他: 悪性甲状腺 尰の肺転移, 日本胸部嵒床, 32 : $332-346$, 1973.

20) Lindsay, S.: Carcinoma of the thyroid. Charles C. Thomas, Springfield, 1960. 